\title{
Peningkatan kemampuan spasial dan self-efficacy siswa melalui model discovery learning berbasis multimedia
}

\author{
Hidayah Nurul Fajri, Rahmah Johar, M. Ikhsan ${ }^{1}$
}

\begin{abstract}
Abstrak: Penelitian ini bertujuan untuk mengetahui peningkatan kemampuan spasial melalui penerapan model pembelajaran discovery learning dengan atau tanpa menggunakan multimedia (GeoGebra), self-efficacy siswa sebelum dan sesudah pembelajaran, dan interaksi antara pembelajaran dengan tingkat kemampuan (level) matematika siswa terhadap peningkatan kemampuan spasial. Populasi penelitian adalah semua siswa kelas VIII SMPN 2 Lhokseumawe. Kelas VIII diambil sebagai kelas eksperimen dan kelas $\mathrm{VIII}_{4}$ sebagai kelas kontrol. Data kemampuan spasial diperoleh dengan tes uraian yang diadopsi dari Maier (1994). Analisis data secara kuantitatif menunjukan bahwa peningkatan kemampuan spasial siswa dengan penerapan model discovery learning berbasis multimedia lebih baik daripada penerapan discovery learning tanpa multimedia. Dalam hal ini, tidak terdapat interaksi antara model pembelajaran discovery learning berbasis multimedia dan discovery learning tanpa multimedia dengan level siswa terhadap peningkatan kemampuan spasial siswa. Analisis kualitatif menunjukan bahwa self-efficacy siswa setelah penerapan model discovery learning meningkat.
\end{abstract} Kata kunci: Discovery Learning; Kemampuan Spasial; Self-Efficacy;
GeoGebra

\begin{abstract}
This research aims to identify the increase of spatial ability through the implementation of discovery learning model with or without the use of multimedia (Geogbera), students' self-efficacy before and after the learning, and the interaction between learning and the level of students' ability towards the increase of spatial ability. The population is all students of grade VIII SMPN 2 Lhokseumawe. Grade $\mathrm{VIII}_{2}$ is selected as the experimental class while Grade $\mathrm{VIII}_{4}$ as the controlled class. Data of spatial ability is collected through essay test adopted from Maier (1994). The quantitative data analysis shows that the increase of students' spatial ability through the implementation of
\end{abstract}

\footnotetext{
${ }^{1}$ Universitas Syiah Kuala, Aceh, Indonesia, nurulhidayah1123@ymail.com
} 
discovery learning model with multimedia is better than discovery learning without multimedia. In this research, there is no interaction between discovery learning model and the level of students' ability in mathematics towards the increase of students' spatial ability. The qualitative analysis shows thatstudent's self-efficacy increases after the learning implementing discovery learning model.

Keywords: Discovery Learning; Spatial Ability; Self-Efficacy; GeoGebra

\section{A. Pendahuluan}

Geometri merupakan salah satu materi matematika yang diajarkan di sekolah. Menurut NCTM (2000), tujuan geometri diajarkan di sekolah adalah agar anak dapat menggunakan visualisasi, mempunyai kemampuan spasial dan pemodelan geometri untuk menyelesaikan masalah. National Academy of Science (Rahman, 2012) menyatakan bahwa setiap siswa harus mengembangkan kemampuan dan penginderaan spasialnya yang sangat berguna dalam memahami relasi dan sifat-sifat dalam geometri untuk memecahkan masalah matematika. Menurut Linn dan Petersen (1985), kemampuan spasial merupakan proses mental dalam mempersepsi, menyimpan, mengingat, mengkreasi, mengubah, dan mengkomunikasikan bangun ruang. Gutierrez (1997) menyatakan ada dua kemampuan utama dalam kemampuan spasial yaitu orientasi spasial dan visualisasi spasial.

Strong dan Roger (2002, dalam Arcat, 2013) mendefinisikan orientasi spasial sebagai pemahaman dari rangkaian unsur dalam suatu stimulus spasial yang tidak dikacaukan oleh perubahan orientasi pada konfigurasi spasial yang muncul. Visualisasi spasial didefinisikan sebagai kemampun secara mental untuk memanipulasi, memutar, atau membalik suatu gambar. Mengingat kemampuan siswa untuk mengamati hubungan posisi objek dalam ruang (kemampuan spasial) masih pada tingkat kurang memuaskan. Hal ini berdasarkan observasi awal yang peneliti lakukan pada tahun 2014. Peneliti menemukan 2 dari 10 siswa tidak mempunyai kesulitan pada dimensi kemampuan spasial, 3 siswa memiliki kesulitan pada dimensi kemampuan relasi, dan 5 siswa memiliki kesulitan pada dimensi kemampuan orientasi. Artinya siswa merasa kesulitan dalam 
menghubungkan bagian-bagian visual dalam sisi bangun ruang dan belum mampu memprediksi bangun ruang bila dilihat dari berbagai sudut pandang.

Menurut Maier (1994) kemampuan spasial dibagi menjadi lima dimensi yaitu: a) dimensi kemampuan persepsi, b) dimensi kemampuan visualisasi, c) dimensi kemampuan rotasi, d) dimensi kemampuan relasi, dan e) dimensi kemampuan orientasi. Menurut Guay dan McDaniel (1977) kemampuan spasial mempunyai hubungan positif dengan matematika pada anak usia sekolah. Sherman (1980) menemukan bahwa matematika dan kemampuan spasial mempunyai korelasi yang positif pada anak usia sekolah. Jika rasa percaya diri siswa mampu menguasai kemampuan spasial dalam geometri, maka ini akan menumbuhkan sikap yang positif. Rasa percaya diri (self-efficacy) siswa mampu menguasai kemampuan spasial dalam geometri, maka ini akan menumbuhkan sikap yang positif. Sikap positif tersebut dapat terlihat dari kesungguhan mengikuti pelajaran, menyelesaikan tugas dengan baik, berpartisipasi aktif selama pembelajaran, menyelesaikan tugas-tugas dengan tuntas dan tepat waktu, serta merespon baik tantangan yang diberikan guru.

Bandura (1997) mendefinisikan self-efficacy sebagai keyakinan seseorang terhadap kemampuannya untuk mengatur dan melaksanakan tindakan-tindakan untuk mencapai tujuan yang ditetapkan, dan berusaha untuk menilai tingkatan dan kekuatan di seluruh kegiatan dan konteks. Bandura dan Locke (2003) menyatakan bahwaself-efficacy menunjukkan tingkat keyakinan siswa terhadap kemampuan diri dalam menyelesaikan berbagai masalah matematika juga mempengaruhi peningkatan hasil belajarnya. Bandura dan Locke (2003) menyatakan ada dua proses belajar yang terpenting, yaitu: a) proses belajar learning by observation yaitu manusia belajar melalui pengamatan terhadap perilaku orang lain, dan b) proses belajar vicarious learning yaitu manusia belajar mengamati konsekuensi perilaku orang lain. Adapun pengukuran self-efficacy dalam penelitian ini difokuskan pada empat karakteristik yang diadaptasi dari Handayani (2012) yaitu: a) percaya pada kemampuan sendiri, b) bertindak mandiri dalam mengambil keputusan, c) memiliki konsep diri yang positif, dan d) berani mengungkapkan pendapat.

Berdasarkan masalah di atas dapat disimpulkan bahwa terdapat kaitan antara kemampuan spasial dan keyakinan siswa (self-efficacy). Oleh 
karena itu, guru harus memeriksa kembali cara mengajar yang terkadang belum cocok dengan siswa. Proses pembelajaran harus disajikan dalam berbagai cara, misalnya pembelajaran dengan menggunakan modelmodel pembelajaran yang telah dikembangkan berdasarkan teori-teori pembelajaran matematika, atau menggunakan teknologi multimedia, sehingga siswa belajar matematika lebih menyenangkan dan akan menimbulkan rasa kenyamanan saat proses pembelajaran matematika berlangsung.

Untuk mengatasi permasalahan di atas guru perlu menerapkan model pembelajaran yang sesuai, salah satu model yang sesuai adalah model discovery learning. Menurut Sund (1975) discovery learning adalah proses belajar yang di dalamnya tidak disajikan suatu konsep dalam bentuk jadi tetapi siswa dituntut untuk mengorganisasi sendiri cara belajarnya dalam menemukan konsep. Model discovery learning merupakan suatu model pengajaran yang menitikberatkan pada aktifitas siswa dan siswa memiliki kesempatan untuk terlibat secara aktif dalam pembelajaran tersebut. Dalam proses pembelajaran dengan model ini, guru bertindak sebagai pembimbing dan fasilitator. Guru memberikan kesempatan muridnya untuk menjadi seorang problem solver, seorang ilmuwan, sejarawan, atau ahli matematika. Bahan ajar tidak disajikan dalam bentuk akhir, tetapi siswa dituntut untuk melakukan berbagai kegiatan menghimpun informasi, membandingkan, mengkategorikan, menganalisis, mengintegrasikan, mereorganisasikan bahan serta membuat kesimpulan-kesimpulan.

Menurut Bell (1978, dalam Supriyanto, 2014), tujuan spesifik dari model discovery learning yaitu: a) dalam penemuan siswa memiliki kesempatan untuk terlibat secara aktif dalam pembelajaran, 2) kenyataan menunjukan bahwa partisipasi siswa dalam pembelajaran meningkat ketika penemuan digunakan, 3) melalui pembelajaran dengan penemuan, siswa belajar menemukan pola dalam situasi konkrit maupun abstrak, juga siswa banyak meramalkan (extrapolate) informasi tambahan yang diberikan, 4) siswa belajar merumuskan strategi tanya jawab yang tidak rancu dan menggunakan tanya jawab untuk memperoleh informasi yang bermanfaat dalam menemukan, 5) membantu siswa membentuk cara kerja bersama yang efektif, saling membagi informasi, serta mendengar dan menggunakan ide-ide orang lain, 6) menunjukan bahwa 
keterampilan-keterampilan, konsep-konsep dan prinsip-prinsip yang dipelajari melalui penemuan lebih bermakna dan 7) lebih mudah ditransfer untuk aktifitas baru dan diaplikasikan dalam situasi belajar yang baru.

Menurut Joyce dan Weil (1992), keuntungan discovery learning dapat membantu siswa mengembangkan disiplin intelektual dan kebutuhan keterampilan untuk membangkitkan rasa ingin tahu dan mencari jawaban dari keingintahuannya. Roestiyah (2008) menambahkan kelebihan model discovery learning yaitu: 1) siswa aktif dalan kegiatan pembelajaran, 2) dapat membangkitkan kegairahan belajar pada siswa, 3) memberikan kesempatan kepada siswa untuk berkembang dan maju sesuai dengan kemampuannya masing-masing, 4) membantu siswa untuk memperkuat dan menambah kepercayaan pada diri sendiri dengan proses penemuan sendiri, 5) siswa akan dapat mentransfer pengetahuan ke dalam berbagai konteks, 6) strategi pembelajaran berpusat pada siswa tidak pada guru, dan 7) guru hanya sebagai teman belajar saja dan membantu bila diperlukan.

Carin dan Sand (1989) mengemukakan lima langkah dalam model discovery learning, yaitu: 1) motivation and problem presentation, 2) selection of learning activities, 3) data collection, 4) data processing, 5) closure. Menurut Syah (2004) dalam mengaplikasikan model discovery learning di kelas, ada beberapa prosedur yang harus dilaksanakan dalam kegiatan belajar mengajar secara umum, yaitu :1) stimulation (stimulasi/pemberian rangsangan), 2) problem statement (pernyataan/ identifikasi masalah), 3) data collection (pengumpulan data), 4) data processing (pengolahan data), 5) verification(pemuktahiran/pembuktian), dan 6) generalization (menarik kesimpulan/generalisasi). Dalam penelitian ini langkah yang digunakan dalam proses pembelajaran di kelas menggunakan langkah menurut Syah (2004).

Menurut Hohenwarter dan Fuchs (2004), GeoGebra sangat bermanfaat sebagai media pembelajaran matematika dengan beragam aktivitas, yaitu: 1) sebagai media demonstrasi dan visualisasi, dalam pembelajaran yang bersifat tradisional guru memanfaatkan GeoGebra untuk mendemonstrasikan dan memvisualisasikan konsep-konsep matematika tertentu, 2) sebagai alat bantu konstruksi, dalam pembelajaran geogebra digunakan untuk memvisualisasikan konstruksi 
konsep matematika tertentu, misalnya mengkonstruksi lingkaran dalam maupun lingkaran luar segitiga, atau garis singgung, dan 3) sebagai alat bantu proses penemuan, dalam pembelajaran geogebra digunakan sebagai alat bantu bagi siswa untuk menemukan suatu konsep matematis, misalnya tempat kedudukan titik-titik atau karakteristik grafik parabola. Manfaat GeoGebra dalam penelitian yaitu: 1) membantu siswa melihat apa yang berubah ketika guru mengubah objek geometri, 2) saat mempelajari materi kubus dan balok, siswa dapat melihat bentuk kubus dan balok dari berbagai sudut pandang, 3) siswa mampu memvisualisasikan bentuk kubus dan balok yang tidak dilakukan saat menggambar di kertas, dan 4) siswa mampu bereksperimen secara luas dan bebas serta mencoba banyak hal untuk menemukan solusi sendiri terhadap suatu masalah geometri.

Berdasarkan latar belakang masalah di atas, penelitian ini akan menjawab beberapa pertanyaan, yaitu: 1) apakah peningkatan kemampuan spasial siswa dengan penerapan model discovery learning berbasis multimedia sama dengan peningkatan kemampuan spasial siswa dengan penerapan model discovery learning tanpa multimedia? 2) bagaimana self-efficacy siswa sebelum dan sesudah penerapan model discovery learning berbasis multimedia? 3) apakah terdapat interaksi antara pembelajaran dengan level siswa (tinggi, sedang dan rendah) terhadap peningkatan kemampuan spasial?

\section{B. Metode Penelitian}

Penelitian ini merupakan penelitian eksperimen dengan pendekatan kuantitatif untuk memperoleh gambaran tentang kemampuan spasial siswa dan kualitatif untuk mengetahui self-efficacy siswa. Terdapat dua kelompok sampel yaitu kelompok ekperimen sebagai kelas dengan penerapan model discovery learning berbasis multimedia dan kelompok kontrol sebagai kelas dengan penerapan model discovery learning tanpa multimedia. Populasi dalam penelitian ini adalah siswa kelas VIII SMP Negeri 2 Lhokseumawe. Peneliti melakukan penelitian di sekolah tersebut dengan pertimbangan telah menerapkan kurikulum 2013 dan merupakan sekolah dengan akreditasi sangat baik (A). Sampel diambil dengan menggunakan teknik random sampling yaitu cara pengambilan sampel secara acak, dimana semua anggota populasi diberi kesempatan atau 
peluang yang sama untuk terpilih menjadi anggota sampel. Sampel yang terpilih adalah kelas $\mathrm{VIII}_{2}$ sebagai kelas eksperimen penerapan model discovery learning berbasis multimedia, dan kelas $\mathrm{VIII}_{4}$ sebagai kelas kontrol dengan dengan penerapan model discovery learning tanpa multimedia.

Instrumen tes yang digunakan dalam penelitian ini diadopsi dari Maier (1994) berupa soal uraian.Soal uraian tersebut memuat indikator/dimensi kemampuan spasial yang digunakan untuk mengukur kemampuan spasial siswa, dan memperhatikan aspek-aspek dari kemampuan spasial. Dimensi kemampuan spasial dalam penelitian ini yaitu: 1) dimensi kemampuan persepsi, kemampuan persepsi merupakan proses mental dalam memprediksi kedalaman suatu bangunan ruang, miring atau tidaknya suatu bangunan terhadap bidang vertikal ataupun horizontal, 2) dimensi kemampuan visualisasi, emampuan visualisasi merupakan kemampuan mental dalam memvisualisasikan konfigurasi bangun ruang menjadi jaring-jaring yang tepat atau sebaliknya, 3) dimensi kemampuan rotasi, kemampuan rotasi merupakan kemampuan mental dalam memprediksi gambar bangun ruang ketika benda diputar, 4) dimensi kemampuan relasi, kemampuan relasi merupakan kemampuan mental dalam menghubungkan bagian-bagian visual dalam sisi bangun ruang, dan 5) dimensi kemampuan orientasi, kemampuan orientasi kemampuan mental untuk memprediksi visual bangun ruang bila dilihat dari berbagai sudut pandang. Instrumen skala self-efficacy matematika siswa berbentuk angket yang digunakan untuk mengetahui pengaruh pembelajaran discovery learning terhadap self-efficacy siswa. Untuk penilaian soal uraian berdasarkan rubrik dibawah ini:

Tabel 1. Rubrik Penilaian Kemampuan Spasial

\begin{tabular}{|c|c|c|c|c|c|c|}
\hline $\begin{array}{l}\text { Kriteria } \\
\text { Indikator }\end{array}$ & $\begin{array}{l}\text { No } \\
\text { So- } \\
\text { al }\end{array}$ & $\begin{array}{c}\text { Bob } \\
\text { ot }\end{array}$ & 1 & 2 & 3 & 4 \\
\hline $\begin{array}{l}\text { Menyata- } \\
\text { kan } \\
\text { kedudukan } \\
\text { antar } \\
\text { unsur- } \\
\text { unsur suatu } \\
\text { bangun }\end{array}$ & 2 & 16 & $\begin{array}{l}\text { Tidak mampu } \\
\text { menjawab } \\
\text { dan } \\
\text { menyatakan } \\
\text { kedudukan } \\
\text { unsur-unsur } \\
\text { dari kubus }\end{array}$ & $\begin{array}{l}\text { Mampu } \\
\text { menjawab } \\
\text { dan } \\
\text { menyatakan2 } \\
5 \% \geq 50 \% \\
\text { unsur yang } \\
\text { ditanya dan }\end{array}$ & $\begin{array}{l}\text { Mampu } \\
\text { menjawab } \\
\text { dan } \\
\text { menyatakan } \\
\text { lebih dari } \\
\text { atau sama } \\
\text { dengan 50\% }\end{array}$ & $\begin{array}{l}\text { Mampu } \\
\text { menjawab } \\
\text { dan } \\
\text { menyatakan } \\
\text { dengan tepat } \\
\text { unsur-unsur } \\
\text { dari kubus }\end{array}$ \\
\hline
\end{tabular}




\begin{tabular}{|c|c|c|c|c|c|c|}
\hline ruang & & & $\begin{array}{l}\text { maupun } \\
\text { balok }\end{array}$ & $\begin{array}{l}\text { benar, tetapi } \\
\text { tidak dapat } \\
\text { membedakan } \\
\text { kedudukan } \\
\text { antar unsur- } \\
\text { unsur kubus } \\
\text { dan balok }\end{array}$ & $\begin{array}{l}\text { unsur-unsur } \\
\text { dari kubus } \\
\text { saja atau } \\
\text { balok saja } \\
\text { tetapi belum } \\
\text { bisa } \\
\text { membedakan } \\
\text { antara kubus } \\
\text { dan balok }\end{array}$ & $\begin{array}{l}\text { dan balok } \\
\text { secara } \\
\text { lengkap } \\
(100 \%)\end{array}$ \\
\hline $\begin{array}{l}\text { Mempredik } \\
\text { si gambar } \\
\text { bangun } \\
\text { ruang } \\
\text { ketika } \\
\text { benda } \\
\text { diputar. }\end{array}$ & 4 & 10 & $\begin{array}{l}\text { Tidak mampu } \\
\text { menentukan } \\
\text { titik-titik pada } \\
\text { balok yang } \\
\text { diputar sama } \\
\text { sekali }\end{array}$ & $\begin{array}{l}\text { Hanya } \\
\text { mampu } \\
\text { menentukan } \\
25 \% \geq 50 \% \\
\text { titik-titik dari } \\
\text { balok yang } \\
\text { diputar }\end{array}$ & $\begin{array}{l}\text { Mampu } \\
\text { menemukan } \\
\text { lebih dari } \\
\text { atau sama } \\
\text { dengan 50\% } \\
\text { titik-titik dari } \\
\text { balok yang } \\
\text { diputar }\end{array}$ & $\begin{array}{l}\text { Mampu } \\
\text { menemukan } \\
\text { semua } \\
(100 \%) \text { titik- } \\
\text { titik dari } \\
\text { balok yang } \\
\text { diputar }\end{array}$ \\
\hline $\begin{array}{l}\text { Menggamb } \\
\text { ar bentuk } \\
\text { atau posisi } \\
\text { suatu objek } \\
\text { geometri } \\
\text { yang } \\
\text { dipandang } \\
\text { dari sudut } \\
\text { pandang } \\
\text { tertentu }\end{array}$ & 7 & 24 & $\begin{array}{l}\text { Tidak mampu } \\
\text { membayangk } \\
\text { an dan } \\
\text { menghitung } \\
\text { posisi kubus } \\
\text { dan balok } \\
\text { sama sekali }\end{array}$ & $\begin{array}{l}\text { Hanya } \\
\text { mampu } \\
\text { membayangk } \\
\text { an dan } \\
\text { menghitung } \\
25 \% \geq 50 \% \\
\text { posisi kubus } \\
\text { saja atau } \\
\text { balok saja }\end{array}$ & $\begin{array}{l}\text { Mampu } \\
\text { membayangk } \\
\text { an dan } \\
\text { menghitung } \\
\text { posisi kubus } \\
\text { dan balok } \\
\text { lebih dari } \\
\text { atau sama } \\
\text { dengan } 50 \%\end{array}$ & $\begin{array}{l}\text { Mampu } \\
\text { membayang- } \\
\text { kan dan } \\
\text { menghitung } \\
\text { posisi kubus } \\
\text { dan balok } \\
\text { dengan tepat }\end{array}$ \\
\hline $\begin{array}{l}\text { Mengkon- } \\
\text { truksi dan } \\
\text { mempresen } \\
\text { tasikan } \\
\text { model- } \\
\text { model } \\
\text { geometri } \\
\text { yang } \\
\text { digambar } \\
\text { pada } \\
\text { bidang } \\
\text { datar }\end{array}$ & 1 & 10 & $\begin{array}{l}\text { Tidak mampu } \\
\text { mengkoktruk } \\
\text { si dan } \\
\text { mempresenta } \\
\text { sikan gambar } \\
\text { kubus dan } \\
\text { balok }\end{array}$ & $\begin{array}{l}\text { Hanya } \\
\text { mampu } \\
\text { mengkontruk } \\
\text { si salah } \\
\text { satunya saja }\end{array}$ & $\begin{array}{l}\text { Mampu } \\
\text { mengkontrusi } \\
\text { dan } \\
\text { mempresenta } \\
\text { sikan kubus } \\
\text { dan balok } \geq \\
50 \%\end{array}$ & $\begin{array}{l}\text { Mampu } \\
\text { mengkontruk } \\
\text { si dan } \\
\text { mempresenta } \\
\text { sikan kubus } \\
\text { dan balok } \\
\text { secara } \\
\text { lengkap }\end{array}$ \\
\hline $\begin{array}{l}\text { Menduga } \\
\text { dan } \\
\text { menentuka }\end{array}$ & 3 & 16 & $\begin{array}{l}\text { Tidak mampu } \\
\text { menduga dan } \\
\text { menentukan }\end{array}$ & $\begin{array}{l}\text { Hanya } \\
\text { mampu } \\
\text { menduga }\end{array}$ & $\begin{array}{l}\text { Mampu } \\
\text { menduga } \geq \\
50 \% \text { dan }\end{array}$ & $\begin{array}{l}\text { Mampu } \\
\text { menduga dan } \\
\text { menentukan }\end{array}$ \\
\hline
\end{tabular}




\begin{tabular}{|l|c|c|l|l|l|l|}
\hline $\begin{array}{l}\text { n ukuran } \\
\text { sebenarnya } \\
\text { dari } \\
\text { stimulus } \\
\text { visual suatu } \\
\text { objek }\end{array}$ & 5 & 14 & $\begin{array}{l}\text { ukurannya } \\
\text { kubus dan } \\
\text { balok sama } \\
\text { sekali }\end{array}$ & $\begin{array}{l}\text { 25\% } \geq 50 \% \\
\text { kubus saja } \\
\text { atau balok } \\
\text { saja tetapi } \\
\text { tidak dapat } \\
\text { menentukan } \\
\text { ukurannya }\end{array}$ & $\begin{array}{l}\text { menentukan } \\
\text { ukuran kubus } \\
\text { dan balok } \\
\text { tetapibelum } \\
\text { lengkap }\end{array}$ & $\begin{array}{l}\text { ukuran kubus } \\
\text { dan balok } \\
\text { secara benar } \\
\text { dan lengkap }\end{array}$ \\
\hline Jumlah & 7 & 100 & & & & \\
\hline
\end{tabular}

\section{Temuan dan Pembahasan}

\section{Peningkatan Kemampuan Spasial}

Berdasarkan hasil pengujian normalitas dan homogenitas, data $\mathrm{N}$ gain kemampuan spasial dari kelas eksperimen dan kelas control berdistribusi normal dan homogen. Untuk mengetahui perbedaan peningkatan kemampuan spasial dilakukan uji-t dan diperoleh nilai thitung adalah 3,643 dengan t-tabel 2,00 dengan kesimpulan t-hitung $>\mathrm{t}$ tabel, maka $\mathrm{H}_{0}$ ditolak dan dapat disimpulkan bahwa peningkatan kemampuan spasial siswa dengan penerapan model discovery learning berbasis multimedia lebih baik daripada siswa yang dengan penerapan model discovery learning tanpa multimedia.

Berdasarkan hasil perhitungan anava dua jalur menunjukkan bahwa nilai sig. pembelajaran discovery learning berbasis multimedia sebesar 0,00 , level siswa dengan pembelajaran discovery learning berbasis multimedia sebesar 0,019 dan interaksi antara pembelajaran dengan level sebesar 0,159 dan lebih besar dari $\alpha=0,05$ yaitu sehingga $H_{0}$ diterima dan Ha ditolak. Dengan demikian dapat disimpulkan bahwa tidak terdapat interaksi antara pembelajan dengan level siswa (tinggi, sedang, rendah) terhadap peningkatan kemampuan spasial siswa.

Dari hasil pre-tes dan pos-tes yang diberikan kepada siswa juga didapat peningkatan dari tiap dimensi atau indikator kemampuan spasial. Secara umum peningkatan kemampuan spasial tiap dimensinya dapat dilihat dari Tabel 2. 
Tabel 2. Persentase Hasil Jawaban Siswa

\begin{tabular}{|c|c|c|c|c|c|c|c|c|c|c|c|c|c|c|}
\hline \multicolumn{15}{|c|}{ Dimensi Kemampuan Spasial } \\
\hline \multirow[t]{3}{*}{$\mathrm{Kr}$} & \multirow{2}{*}{\multicolumn{2}{|c|}{$\begin{array}{c}\text { Persepi } \\
1 \\
\end{array}$}} & \multicolumn{4}{|c|}{ Visualisasi } & \multirow{2}{*}{\multicolumn{2}{|c|}{$\begin{array}{c}\text { Rotasi } \\
4\end{array}$}} & \multicolumn{4}{|c|}{ Relasi } & \multirow{2}{*}{\multicolumn{2}{|c|}{$\begin{array}{c}\text { Orientasi } \\
7\end{array}$}} \\
\hline & & & & & & & & & & & & & & \\
\hline & Pre & Post & Pre & Post & Pre & Post & Pre & Post & Pre & Post & Pre & Post & Pre & Post \\
\hline 1 & 0 & 0 & 0 & 0 & 0 & 0 & 0 & 0 & 0 & 0 & 0 & 0 & 0 & 0 \\
\hline 2 & 34.8 & 0 & 34.8 & 0 & 0 & 0 & 75.4 & 0 & 34.8 & 0 & 92.8 & 0 & 84.1 & 0 \\
\hline 3 & 63.8 & 49.3 & 63.8 & 63.8 & 100 & 0 & 23.2 & 26.1 & 60.9 & 75.4 & 5.8 & 46.4 & 14.5 & 17.4 \\
\hline 4 & 0 & 49.3 & 0 & 34.8 & 0 & 100 & 0 & 72.5 & 2.9 & 11.6 & 0 & 52.2 & 0 & 81.2 \\
\hline$\Sigma$ & 100 & 100 & 100 & 100 & 100 & 100 & 100 & 100 & 100 & 100 & 100 & 100 & 100 & 100 \\
\hline
\end{tabular}

Dari soal nomor 1 pada dimensi persepsi menunjukkan bahwa kemampuan siswa dalam memprediksi kedalaman suatu bangun ruang, miring atau tidaknya suatu bangun terhadap bidang vertikal maupun horizontal sebelum penerapan model discovery learning berbasis multimedia sebesar $0 \%$ dan $49,3 \%$ setelah penerapan model discovery learning berbasis multimedia. Persentase dimensi visualisasi dimana kemampuan siswa dalam memvisualisasikan bangun ruang menjadi jaringjaring yang tepat pada soal nomor 3 persentase sebelum penerapan model discovery learning berbasis multimedia sebesar 0\% dan $34.8 \%$ setelah penerapan model discovery learning berbasis multimedia. Sedangkan pada soal nomor 5 persentase sebelum penerapan model discovery learning berbasis multimediasebesar 0\% dan 100\% setelah penerapan model discovery learning berbasis multimedia. Untuk persentase soal nomor 4 pada dimensi rotasi menunjukkan bahwa kemampuan siswa dalam memprediksi gambar bangun ruang ketika benda tersebut diputar sebelum penerapan model discovery learning berbasis multimedia sebesar $0 \%$ dan $72,5 \%$ setelah penerapan model discovery learning berbasis multimedia.

Persentase dimensi relasi kemampuan siswa dalam menghubungkan bagian-bagian visual dalam sisi bangun ruang pada soal nomor 2 sebelum penerapan model discovery learning berbasis multimedia 2,9\% dan sebesar $11,6 \%$ setelah penerapan model discovery learning berbasis multimedia. Sedangkan pada soal nomor 6 persentase sebelum penerapan model discovery learning berbasis multimediasebesar $0 \%$ dan $52,2 \%$ setelah penerapan model discovery learning berbasis 
multimedia.Untuk persentase untuk dimensi orientasi menunjukkan bahwa siswa mampu memprediksi visual bangun ruang bila di lihat dari berbagai sudut pandang sebelum penerapan model discovery learning berbasis multimedia sebesar $0 \%$ dan $81,2 \%$ setelah penerapan model discovery learning berbasis multimedia.

Selanjutnya, jika model discovery learning berbasis multimedia dan tanpa multimedia dibandingkan dengan kelas konvensional terdapat perbedaan peningkatan kemampuan spasial. Perbedaan yang timbul tersebut menunjukkan bahwa proses pembelajaran konvensional kurang dapat meningkatkan kemampuan spasial siswa. Hal ini terlihat pada proses pembelajaran yang langsung memberikan materi pelajaran kepada siswa kemudian diiringi diberikannya contoh soal kemampuan spasial. Ini menyebabkan siswa menerima informasi secara pasif sehingga kemampuan spasial siswa kurang didorong.

Dari hasil penelitian di atas, dapat disimpulkan bahwa pembelajaran dengan model discovery learning berbasis multimedia dapat meningkatkan kemampuan spasial siswa. Hal ini sesuai dengan penelitian Supriyanto (2014) yang menunjukkan bahwa pembelajaran discovery learning dapat meningkatkan hasil dan keaktifan belajar siswa.Pada model discovery learning, yang dapat menunjang peningkatan kemampuan spasial siswa adalah dimana siswa terlibat langsung dalam mengidentifikasi masalah yang siswa terima, mengumpulkan informasi mengenai materi yang sedang siswa pelajari dan siswa mengolah data informasi yang diperoleh sehingga siswa menemukan penyelesaian dari masalah yang siswa terima.

\section{Peningkatan Self-Efficacy}

Angket self-efficacy siswa terdiri dari 30 pernyataan (18 pernyataan positif dan 12 pernyataan negatif) yang harus direspons oleh siswa sebelum dan sesudah penerapan model discovery learning berbasis multimedia. 
Tabel 3a. Rangkuman Hasil Angket Self Efficacy Sebelum Penerapan Model Discovery Learning Berbasis Multimedia

\begin{tabular}{|c|c|c|c|c|}
\hline $\begin{array}{l}\text { Rumusan } \\
\text { Masalah }\end{array}$ & $\begin{array}{c}\text { Aspek/ } \\
\text { Karakteristik }\end{array}$ & Tujuan & $\begin{array}{l}\text { Persenta- } \\
\text { se }\end{array}$ & $\begin{array}{c}\text { Interpre } \\
\text {-tasi }\end{array}$ \\
\hline \multirow{4}{*}{$\begin{array}{l}\text { Bagaimana } \\
\text { self-efficacy } \\
\text { siswa } \\
\text { sebelum } \\
\text { penerapan } \\
\text { model } \\
\text { discovery } \\
\text { learning } \\
\text { berbasis } \\
\text { multimedia } \\
\text { ? }\end{array}$} & $\begin{array}{l}\text { Aspek Percaya } \\
\text { Kemampuan } \\
\text { Sendiri }\end{array}$ & $\begin{array}{l}\text { a. Self-efficacy siswa } \\
\text { pada aspek percaya } \\
\text { kemampuan sendiri } \\
\text { sebelum penerapan } \\
\text { model discovery } \\
\text { learning berbasis } \\
\text { multimedia }\end{array}$ & $64 \%$ & Baik \\
\hline & $\begin{array}{l}\text { Bertindak } \\
\text { Mandiri dalam } \\
\text { Mengambil } \\
\text { Keputusan }\end{array}$ & \begin{tabular}{|l} 
b. Self-efficacy siswa \\
pada aspek bertindak \\
mandiri dalam \\
mengambil keputusan \\
sebelum penerapan \\
model discovery \\
learning berbasis \\
multimedia
\end{tabular} & $64 \%$ & Baik \\
\hline & $\begin{array}{l}\text { Memiliki } \\
\text { Konsep Diri } \\
\text { yang Positif }\end{array}$ & \begin{tabular}{|l} 
c. Sel-fefficacy siswa \\
pada aspek memiliki \\
konsep diri yang \\
positifsebelum \\
penerapan model \\
discovery learning \\
berbasis multimedia
\end{tabular} & $69 \%$ & Baik \\
\hline & $\begin{array}{l}\text { Berani } \\
\text { Mengungkapka } \\
\text { n Pendapat }\end{array}$ & $\begin{array}{l}\text { d. Self-efficacy siswa } \\
\text { pada aspek berani } \\
\text { mengungkapkan } \\
\text { pendapat sebelum } \\
\text { penerapan model } \\
\text { discovery learning } \\
\text { berbasis multimedia }\end{array}$ & $57 \%$ & Cukup \\
\hline
\end{tabular}

Berdasarkan deskripsi hasil penelitian yang telah diuraikan tabel 3a di atas, diketahui bahwa persentase self-efficacy siswa sebelum penerapan model discovery learning berbasis multimedia terhadap aspek percaya kemampuan sendiri adalah 64\% (kriteria baik). Pada aspek bertindak mandiri dalam mengambil keputusan juga mendapatkan persentase $64 \%$ (kriteria baik).Sedangkan untuk aspek memiliki konsep 
diri yang positif persentasenya adalah 69\% (kriteria baik). Selanjutnya persentase pada aspek berani mengungkapkan pendapat adalah $57 \%$ (kriteria cukup).

Tabel 3b. Rangkuman Hasil Angket Self Efficacy Sesudah Penerapan Model Discovery Learning Berbasis Multimedia

\begin{tabular}{|c|c|c|c|c|}
\hline $\begin{array}{c}\text { Rumusan } \\
\text { Masalah }\end{array}$ & $\begin{array}{c}\text { Aspek/ } \\
\text { Karakteristik }\end{array}$ & Tujuan Penelitian & $\begin{array}{c}\text { Persentas } \\
\text { e }\end{array}$ & $\begin{array}{c}\text { Interpre } \\
\text {-tasi }\end{array}$ \\
\hline \multirow{4}{*}{$\begin{array}{l}\text { Bagaimana } \\
\text { self-efficacy } \\
\text { siswa } \\
\text { sesudah } \\
\text { penerapan } \\
\text { model } \\
\text { discovery } \\
\text { learning } \\
\text { berbasis } \\
\text { multimedia } \\
\text { ? }\end{array}$} & $\begin{array}{l}\text { Percaya } \\
\text { Kemampuan } \\
\text { Sendiri }\end{array}$ & $\begin{array}{l}\text { a. Self-efficacy siswa } \\
\text { pada aspek percaya } \\
\text { kemampuan sendiri } \\
\text { sesudah penerapan } \\
\text { model discovery } \\
\text { learning berbasis } \\
\text { multimedia }\end{array}$ & $81 \%$ & $\begin{array}{l}\text { Baik } \\
\text { Sekali }\end{array}$ \\
\hline & $\begin{array}{l}\text { Bertindak } \\
\text { Mandiri } \\
\text { dalam } \\
\text { Mengambil } \\
\text { Keputusan }\end{array}$ & $\begin{array}{l}\text { b. Self-efficacy siswa } \\
\text { pada aspek bertindak } \\
\text { mandiri dalam } \\
\text { mengambil keputusan } \\
\text { sesudah penerapan } \\
\text { model discovery } \\
\text { learning berbasis } \\
\text { multimedia } \\
\end{array}$ & $80 \%$ & Baik \\
\hline & $\begin{array}{l}\text { Memiliki } \\
\text { Konsep Diri } \\
\text { yang Positif }\end{array}$ & $\begin{array}{l}\text { c. Self-efficacy siswa pada } \\
\text { aspek memiliki konsep } \\
\text { diri yang positifsesudah } \\
\text { penerapan model } \\
\text { discovery learning } \\
\text { berbasis multimedia }\end{array}$ & $88 \%$ & $\begin{array}{l}\text { Baik } \\
\text { Sekali }\end{array}$ \\
\hline & $\begin{array}{l}\text { Berani } \\
\text { Mengungkap } \\
\text { kan Pendapat }\end{array}$ & $\begin{array}{l}\text { d. Self-efficacy siswa pada } \\
\text { aspek berani } \\
\text { mengungkapkan } \\
\text { pendapat sesudah } \\
\text { penerapan model } \\
\text { discovery learning } \\
\text { berbasis multimedia }\end{array}$ & $73 \%$ & Baik \\
\hline
\end{tabular}

Berdasarkan deskripsi hasil penelitian yang telah diuraikan tabel $3 \mathrm{~b}$ di atas, diketahui bahwa persentase self-efficacy sesudah penerapan model discovery learning berbasis multimedia siswa terhadap aspek percaya kemampuan sendiri sebesar $81 \%$ (kriteria baik sekali). Untuk 
aspek bertindak mandiri dalam mengambil keputusan sebesar $80 \%$ (kriteria baik), sedangkan persentase untuk aspek memiliki konsep diri yang positif adalah sebesar $88 \%$ (kriteria baik sekali).Selanjutnya persentase pada aspek berani mengungkapkan pendapat adalah sebesar 73\% (kriteria baik).Artinya self-efficacy siswa sesudah penerapan model discovery learning berbasis multimedia lebih baik. Ini menunjukkan model discovery learning berbasis multimedia dapat membantu siswa untuk memperkuat dan menambah kepercayaan pada diri sendiri dengan proses penemuan yang siswa dapat selama pembelajaran dengan software geogebra. Hasil ini sesuai dengan penelitian sebelumnya, Risdianto (2013) yang mengemukakan bahwa terdapat peningkatan self-efficacy matematika antara siswa yang diberi model pembelajaran penemuan terbimbing berbantuan software autograph dengan siswa yang diberi model pembelajaran konvensional.

Selain menggunakan angket, berdasarkan hasil observasi dapat disimpulkan bahwa siswa kelas eksperimen memiliki self-efficacy yang tinggi untuk bertanya kepada guru, maupun mengerjakan soal di papan tulis berdasarkan prosedur pemodelan yang diminta. Siswa telah merasa yakin dengan jawaban mereka karena representasi yang dibuat mengarahkan siswa untuk menyelesaikan soal dengan benar. Ini sejalan dengan pendapat Bandura (1997) yang menyatakan self-efficacy memainkan peranan penting dalam memotivasi siswa yang berhubungan dengan proses pembelajaran. Hasil ini sesuai dengan pendapat de Corte, Verschaffel \& Op'T (2006) yang menyatakan bahwa penyelesaian masalah matematik saat ini difokuskan terhadap sikap dan keyakinan siswa dan kapasitas mereka untuk mengaplikasikan pengetahuan matematika dalam masalah-masalah yang bersifat non-rutin. Mereka juga mendokumentasikan bahwa keyakinan yang kuat dari siswa dapat berfungsi sebagai alat untuk meramalkan (predictor) keberhasilan dan prestasi siswa dalam penyelesaian masalah yang autentik.

\section{Simpulan}

Berdasarkan hasil penelitian dan pembahasan, dapat diambil beberapa simpulan yang berkaitan dengan peningkatan kemampuan 
spasial dan self-efficacy siswa SMP melalui model discovery learning berbasis multimedia, yaitu:

1. Peningkatan kemampuan spasial siswa dengan penerapan model discovery learning berbasis multimedia lebih baik daripada peningkatan kemampuan spasial siswa dengan penerapan model discovery learning tanpa multimedia. Dengan perolehan rata-rata $\mathrm{N}$ gain siswa kelas eksperimen 0,672 dan kelas kontrol 0,672.

2. Self-efficacy siswa setelah penerapan model discovery learning meningkat dengan rincian sebagai berikut:

a. Persentase self-efficacy memberi respon positif terhadap aspek percaya kemampuan sendiri sebelum penerapan model discovery learning berbasis multimedia adalah $64 \%$ (kriteria baik), sedangkan sesudah penerapan model discovery learning berbasis multimedia adalah sebesar 81\% (kriteria baik sekali).

b. Persentase self-efficacy memberi respon positif terhadap aspek bertindak mandiri dalam mengambil keputusan sebelum penerapan model discovery learning berbasis multimedia adalah 64\% (kriteria baik), sedangkan sesudah penerapan model discovery learning berbasis multimedia adalah sebesar $80 \%$ (kriteria baik).

c. Persentase self-efficacy memberi respon positif terhadap aspek memiliki konsep diri yang positifsebelum penerapan model discovery learning berbasis multimedia adalah 69\% (kriteria baik), sedangkan sesudah penerapan model discovery learning berbasis multimedia adalah sebesar $88 \%$ (kriteria baik sekali).

d. Persentase self-efficacy memberi respon positif terhadap aspek berani mengungkapkan pendapatsebelum penerapan model discovery learning berbasis multimedia adalah $57 \%$ (kriteria cukup), sedangkan sesudah penerapan model discovery learning berbasis multimedia adalah sebesar 73\% (kriteria baik).

3. Tidak terdapat interaksi antara model pembelajaran (discovery learnig berbasis multimedia dan discovery learning tanpa multimedia) dengan level siswa (tinggi, sedang, rendah) terhadap peningkatan kemampuan spasial siswa. 
Penggunaan multimedia dan software untuk pembelajaran matematika di Sekolah Menengah Pertama perlu lebih dikembangkan lagi, agar siswa lebih bisa mengasah kemampuan spasial dan kemampuan matematis lainnya. Adapun saran-saran yang dapat penulis kemukakan, yaitu:

1. Diharapkan bagi para guru untuk lebih memanfaatkan multimedia dalam pembelajaran matematika di sekolah karena penggunaan multimedia dalam pembelajaran matematika di Sekolah Menengah Pertama masih dirasakan sangat kurang, mengingat kecanggihan teknologi dan keberadaan software matematika yang begitu banyak sekarang ini.

2. Software GeoGebra akan sangat baik digunakan dalam pembelajaran matematika karena dapat menampilkan bentuk bangun ruang dari berbagai sudut pandang.

3. Aspek psikologi yang diukur dalam penelitian ini hanya self-efficacy. Masih banyak aspek psikologi lainnya yang menarik untuk diteliti berkaitan dengan prestasi siswa.

\section{Daftar Pustaka}

Arcat. (2013). Meningkatkan kemampuan spasial dan self-efficacy siswa SMP melalui model Kooperatif Tipe STAD berbantuan Wingeom. Program Studi Pendidikan Matematika. Tesis. Sekolah PascaSarjana UPI.

Bandura, A. (1997). Self-efficacy: The exercise of control .New York: Freeman Bandura, A. \& Locke, E. A. (2003). Negative self-efficacy and goal effects revisited. Journal of Applied Psychology. 88(1), 87-99. Doi: 10.1037/00219010.88.1.87

Budiningsih, A. (2005). Belajar dan pembelajaran. Jakarta: Rineka Cipta.

Carin \& Sand, R. B. (1989). Teaching science through discovery. Columbus: Merrill

Djamarah \& Bahri, S. (2002). Rahasia sukses belajar. Jakarta: RinekaCipta.

Guay, R., \& McDaniel, E. (1977). The relationship between mathematics achievement and spatial abilities among elementary school children. Journal for Research in Mathematics Education, 8(3), 211-215. doi:10.2307/748522

Gutierrez, A. (1997). Visualization in 3-dimensional geometry. Proceeding of the 20th Conference of the international Group for the psychology of Mathematics Educationl,3-20. 
Handayani, I. (2012). Penggunaan model method dalam pembelajaran pecahan sebagai upaya meningkatkan kemampuan pemecahan masalah matematik dan self-efficacy siswa Sekolah Dasar. Tesis. Sekolah PascaSarjana UPI.

Hohenwarter, M. \& Fuchs, K. (2008).Combination of dynamic geometry, algebra, and calculus in the software system GeoGebra. Diaskes di www.geogebra.org/publications/pecs_2004.pdf.

Joyce, B \& Weil, M. (1992). Models of teachings. London: Prentice-Hall International.

Linn, M., \& Petersen, A. (1985). Emergence and characterization of sex differences in spatial ability: a meta-analysis. Child Development, 56(6), 1479-1498. doi:10.2307/1130467

Maier, H. (1994). Spatial Geometry And Spatial Ability- How To Make Solid Geometry Solid.

NCTM. (2000). Curriculum and evalution standards for schoool mathematic., Reston, VA: NCTM

Op't Eynde, P., De Corte, E., \& Verschaffel, L. (2006). Accepting emotional complexity: A socio-constructivist perspective on the role of emotions in the mathematics classroom. Educational Studies in Mathematics, 63(2), 193-207.

Rahman, B. (2012). Pembelajaran geometri dengan Wingeom untuk meningkatkan kemampuan spasial dan penalaran matematis siswa. Tesis. Sekolah PascaSarjana UPI.

Roestiyah. N.K. (2008). Strategi Belajar Mengajar. Jakarta: Rineka Cipta.

Sherman, J. (1980). Mathematics, spatial visualization, and related factors: Changes in girls and boys, Grades 8-11. Journal of Educational psychology, 72(4), 476.

Smith, E. L. (1993). Teaching strategies associated with conceptual change learning. Journal of Research in Science Teaching, 30(2), 111-26.

Sugiyono. (2012). Metode penelitian kuantitatif, kualitatif, dan R\&D. Bandung: Alfabeta.

Sund, R.B. (1975). Teaching science through discovery. Columbus, Ohio: Charles Merril Publishing Company.

Supriyanto, B. (2014). Penerapan discovery learning untuk meningkatkan hasil belajar siswa mata pelajaran matematika pokok bahasan keliling dan luas lingkaran. Jurnal: Pancaran, 3, 165-174.

Syah, M. (2004). Psikologi pendidikan. Bandung: Grafindo Persada.

Risdianto, H. (2013). Problem Solving Ability and Self Efficiency SMA with MA

Students IPS Program Through Guided Inquiry Learning Model Assisted Autograph Software in Langsa. Jurnal Pendidikan Matematika PARADIKMA. 6(1), 89-108 